\title{
Seasonal dynamics of arginine ammonification in forest soils of Norway spruce pure stands under different silvicultural practices
}

\author{
Ladislav Holik*, Aleš Kučera, Klement Rejšek, Valerie Vranová \\ Mendel University in Brno, Faculty of Forestry and Wood Technology, Zemědělská 3, CZ - 61300 Brno, Czech Republic
}

\begin{abstract}
Effects of seasonal dynamics and silvicultural practice on ammonification of arginine, one of the proteinogenic amino acids, were assessed in surface organic $\mathrm{H}$-horizon of three Norway spruce pure stands in medium altitudes (600 660 m a.s.l.). Contents of ammonium ions $\mathrm{NH}_{4}^{+}$measured monthly in the field and contents of $\mathrm{NH}_{4}^{+}$after laboratory incubation of these samples with arginine were taken as dependent variables in ANOVA and in linear regression model using generalised linear model. The aim of the analyses was to determine the significance of decomposition of this amino acid in H-horizon of forest soils and to determine categorical and continuous predictors which influence intensity of the ammonification. Laboratory experiments confirmed its close link to seasonal dynamics, as well as to forest management; however the last mentioned was firstly found as less significant when compared within whole season. As regards to seasonal dynamics in forest soils, the highest amount of ammonium ion was released in May and the lowest in July. As regards to the silvicultural practice applied, more ammonium ion was released under mature spruce monoculture, especially in August and May; in the young stands, the method of thinning had no effect on the ammonium ion release. However, the arginine ammonification was found to be influenced by ammonium nitrogen content (slight, less significant negative correlation) and by soil water content (stronger positive significance), especially in the stand with thinning from below. This was concluded to be caused by changes in stand microclimate in function of the silvicultural practice.
\end{abstract}

Key words: ammonium availability; arginine deaminase; forest management; Norway spruce

\section{Introduction}

Nitrogen is an essential element for plant growth (Wang et al.2007). Mineralization and nitrification of soil nitrogen directly affects his income by plants and losses at the interface plant and soil environment (Yang et al. 2008). Soil microorganisms and enzymes are responsible for maintaining soil fertility through degradation and mineralization of organic matter. Changes in conditions for plant growth, such as silvicultural measures necessary aging stands, can cause changes in microbial communities and their biochemical activity and affect the availability of nutrients for plants (Singh \& Singh 2005; Novák et al. 2015). Ammonification of arginine has a significant relationship with the soil microbial biomass and affects their biochemical activity (Davis et al. 1978; Alef \& Kleiner 1986; Singh \& Singh 2005).

Arginine is one of the more than 300 naturally occurring amino acids and only 20/21 of them occur in proteins solely in the form of $\mathrm{L}-\alpha$-amino acids (except glycine which has no chiral carbon) (Moe 2013). The combination of these proteinogenic amino acids form all known proteins. After apearance of dead organic matter in soil, proteinogenic amino acids begin to decompose. Ammonification is an important initial stage of organic matter mineralization when proteins and other organic compounds containing amino groups are decomposed by proteolytic enzymes to amino acids which are further deaminated to ammonium ion $\mathrm{NH}_{4}^{+}$(Abdelal 1979; Bonde et al. 2001; Lin \& Brookes 1999).

The presented study deals with seasonal dynamics of ammonification of arginine, one of the proteinogenic amino acids, in Norway spruce (Picea abies [L.] Karst., Pinaceae) monocultures and the applied silvicultural practice in medium altitudes. The study was focused on the surface organic H-horizon. 


\section{Material and methods}

\subsection{Site description and soil sampling}

The research was carried out at the Rájec-Němčice Ecosystem Station, the Drahanská vrchovina uplands (the Czech Republic), located at $49^{\circ} 29^{\prime} \mathrm{N}$ and $16^{\circ} 43^{\prime} \mathrm{E}$ at an altitude of $600-660 \mathrm{~m}$ a.s.l. Geological subsoil is acid granodiorite, soil type Dystric Cambisol (IUSS Working Group WRB 2006), humus form Humic Mormoder (Klinka et al. 1997). Mean annual air temperature is $6.5^{\circ} \mathrm{C}$ and the mean annual sum of precipitation is $717 \mathrm{~mm}$. From the viewpoint of forestry, the ecosystem station belongs to the 4 th forest vegetation zone (fir beech vegetation zone); forest type Fageta quercina abietina.

The middle-aged stand was divided into several experimental plots $(25 \times 25 \mathrm{~m})$ where different silvicultural practices were carried out. Primarily, seedlings were planted with the spacing $2.5 \times 2 \mathrm{~m}$ on the clearing after felling of the previous mature spruce stand. The spruce stand, aged 33 years, was tended by strong thinning from above and from below with the intensity of $30 \%$. The initial planting density was 4200 trees per ha, tending felling was performed in 1986, 2002 and 2010, reducing the density to 2381 trees per ha.

Three study plots were chosen among silvicultural management practices (SilvPra): i) MSS - mature spruce stand, 105 years, monoculture; ii) STFA - stand thinned from above (middle-aged stand thinned from above), 33 years, monoculture; iii) STFB - stand thinned from below (middle-aged stand thinned from below), 33 years, monoculture. The data collection was performed with the aim to focus on the arginine ammonification process inside the soil system in relation to stand and soil microclimate including MONTH (with categories Apr - April, May, Jun - June, Jul - July, Aug - August, Sept - September) and SilvPra (with categories STFA, STFB and MSS) as qualitative predicting variables and selected soil properties (see below) as quantitative predicting variables. As well, the soil was sampled from organic H horizons (IUSS Working Group WRB 2006) from each SilvPra treatment (one samling plot per treatment) each MONTH through the year 2014 as mixed sample in five repetitions per sampling plot using surface preparation method. The sampling depth was from 2.5 to $4 \mathrm{~cm}$ depending on stratigraphy of surface organic horizons. In the laboratory, the naturally-moist samples were sieved through a $5 \mathrm{~mm}$ sieve, mixed and stored at $5^{\circ} \mathrm{C}$.

\subsection{Soil analysis}

Determination of arginine ammonification rate (Alef \& Kleiner 1986) was based on soil samples incubated with arginine producing the ammonium which is extracted with potassium chloride solution and determined colorimetrically after addition of chromogenic reagents. Deter- mination of ammonium nitrogen in soil extract was performed by Kučera et al. (2013). Determination of mass water content $(\mathrm{w})$ was performed according to Zbíral et al. (2010).

\subsection{Statistical processing}

The key to clarify the relationship between arginine ammonification detected by means of arginine deaminase, the $\mathrm{H}$-horizon of three studied spruce forests throughout the vegetation season was ANOVA, correlation analysis and regression analysis (GLM). Individual dependent variables were the contents of ammonification products $\left(\mathrm{NH}_{4}^{+}\right)$as measured each month and the laboratory-determined values of arginine ammonification in the same soil samples. The arginine ammonification analysis was carried out using two grouping variables: i) months, for the seasonal dynamics, and ii) spruce stands differing in age and the applied silvicultural practice (SilvPra) and finally two continuous variables: i) soil water content and ii) ammonium nitrogen content, which were considered as well predicting factors.

ANOVA was performed as one-way (with the factor being either the month or the silvicultural practice applied) or two-way (the month and the silvicultural practice are tested simultaneously) without and with interactions. The null hypothesis was tested via the p-value and the Tukey's HSD test was used as the multiple comparison post-hoc procedure, with the significance level alpha $=0.05$ (conf. level $=0.95)$. When the direct dependences were studied, the test determined the differences between the individual datasets as statistically significant in all performed analyses of variance.

Relations between observed variables were analysed using Spearman's correlation coefficient $r_{s}$, compared with critical value with significant level alpha $=0.05$ with two-tailed probabilities.

Dependence of arginine ammonification was analysed with use of generalised linear model (GLM) with Gamma distribution and inverse link function. To select optimal model for the dependence explanation, we used AIC: Akaike's an information criterion (Sakamoto et al. 1986) and vif: variance inflation factors (Fox \& Monette 1992). The statistics were carried out in Statistica $\mathrm{Cz}$, version 12 and $\mathrm{R}$ software environment, version 3.2.3 (2015-12-10), The R Foundation for Statistical Computing, using car package version 2.1-1 (Fox \& Weisberg 2015; Lin 2015), ggplot2 package version 2.0.0 (Wickham \& Chang 2016).

\section{Results}

In general, the highest ammonium ion content was found in MSS in August and in May. In other months the content was similar. In STFA and STFB the differences were not as significant except for July and May (Fig. 1). One- 
way ANOVA found both variables significant: MONTH as well SilvPra with $\mathrm{p}-$ values $<0.002$ and $<0.0002$, respectively (Fig. 2).

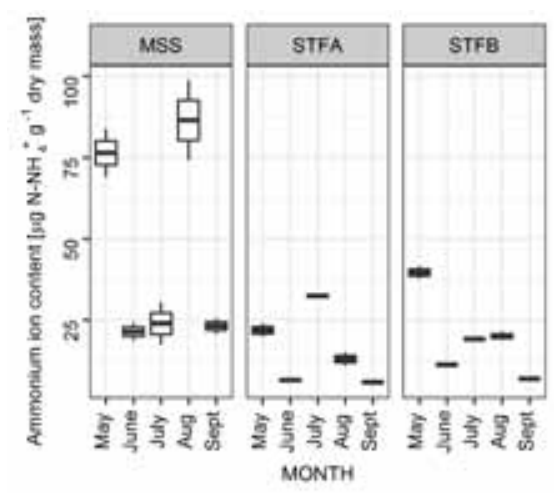

Fig. 1. Ammonium ion content in the H-horizon, seasonal dynamics in three treatments of spruce stand. MSS - mature spruce stand, STFA - stand thinned from above, STFB - stand thinned from below.

(a) $95 \%$ tamily-wise confidence level (b) $95 \%$ family-wise confidence level

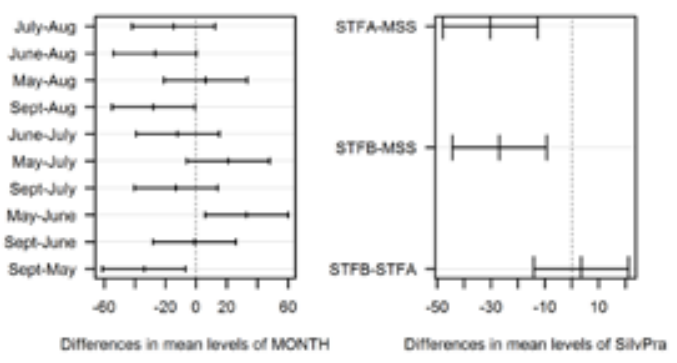

Fig. 2. Post-hoc analysis of ammonium ion concentration following one-way ANOVA with grouping variable (a) MONTH; (b) SilvPra. MSS - mature spruce stand, STFA - stand thinned from above, STFB - stand thinned from below.

Statistically significant differences were found in three comparisons: i) May - September; ii) May - June; iii) August - September. The differences between variables were even more significant using two-way ANOVA (either without or with interactions when $\mathrm{p}$-values for both variables were $<1.02 \mathrm{e}^{-5}$ and $<2 \mathrm{e}^{-15}$, respectively). Therefore, from the viewpoint of seasonal dynamics (i.e. in case of individual months), ANOVA rejected the null hypothesis of the correlation of the statistical data sets and, simultaneously influence of seasonal dynamics of ammonium concentration depends on silvicultural practice.

For silvicultural practice and soil ammonium ion statistically insignificant differences in the content of $\mathrm{NH}_{4}^{+}$in both young stands, with a slightly higher value observed in the stand thinned from below. In the comparison of the young stands with the mature stand, the differences were statistically significant with the higher content of $\mathrm{NH}_{4}^{+}$always found in the mature stand.
The one-way ANOVA for the ammonium ion content revealed differences between MONTH, as well SilvPra (Fig. 2). Significantly the highest content of $\mathrm{NH}_{4}^{+}$was found in the samples collected in May and in August (without mutual significant difference) compared to the June and September.

The ammonium production after addition of arginine was markedly higher in September (Fig. 3). Results of seasonal dynamics of arginine ammonification in laboratory conditions (Fig. 4) are characterized by marked differences within the season. The highest values of the ammonification were detected in September followed by May. These two months were far more active in ammonification, especially the September.

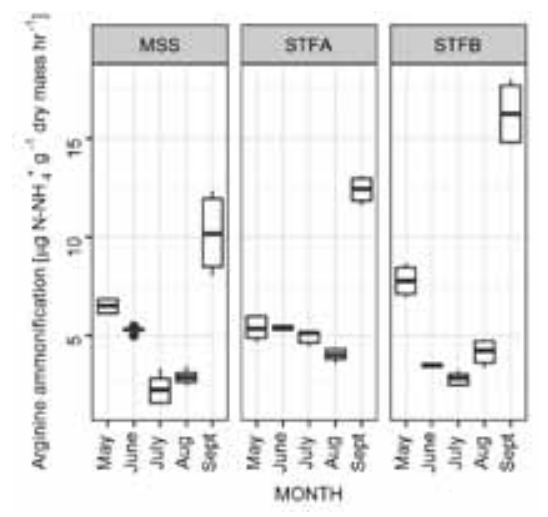

Fig. 3. Production of ammonium ion after addition of arginine, seasonal dynamics of arginine ammonification in H-horizon in spruce stands. MSS - mature spruce stand, STFA - stand thinned from above, STFB - stand thinned from below.

One-way ANOVA of arginine ammonification found the SilvPra as none-significant variable. However, twoway ANOVA revealed significant differences both between the individual MONTH and SilvPra ( $p$-values were $<2 \mathrm{e}^{-16}$ and 0.00115 , respectively). The differences were insignificant only in three cases (in descending order August vs. July, August vs. June; June vs. July). In descending order, in September, the intensity was markedly higher compared to July, August, June and May. The lowest activity was found in July followed by August and June.

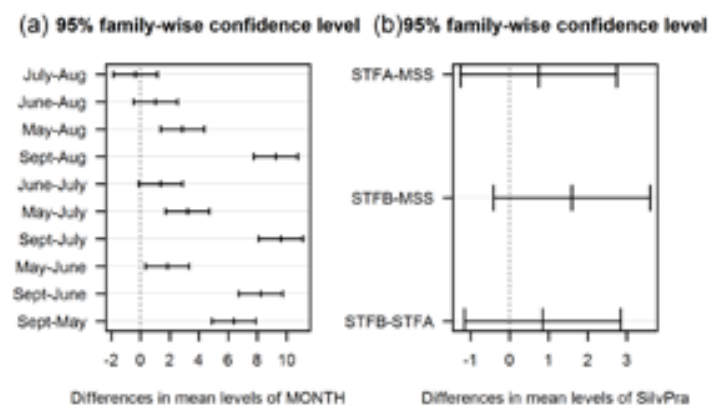

Fig. 4. Post-hoc analysis of arginine ammonification following one-way ANOVA with grouping variable (a) MONTH; (b) SilvPra. MSS - mature spruce stand, STFA - stand thinned from above, STFB - stand thinned from below. 
For ANOVA of SilvPra without and with interactions, p-valueswere 0.00115 and $3.05 \mathrm{e}^{-9}$, respectively. Regarding silvicultural practices applied at the studied plots, the two-way ANOVA revealed more significant differences between both middle-aged and mature stand and rather equal values of the arginine ammonification when compared the middle-aged treatments (STFA vs. STFB).

As regards seasonal dynamics, the arginine ammonification was significantly different in two-way ANOVA both without and with interactions $\left(p<2 \mathrm{e}^{-16}\right)$.

Regarding the minimum values, the data from field and from laboratory were consistent in the summer months when the low amount of ammonium ion in soil corresponded to the low decomposition of arginine in the laboratory.

More ammonium ion was released in soil under the mature spruce monoculture compared to the young stands. Relation between arginine ammonification and its expected higher intensity in the mature stand was not confirmed. In the laboratory experiment, higher arginine ammonification was also found in the soil from the mature stand.

Ammonium nitrogen can be considered a product of arginine ammonification and thus it is expectable that its increased concentration is a result of increased ammonification. Conversely, it can be regarded as a predictor of arginine ammonification which gets stronger with decreasing concentration of $\mathrm{N}-\mathrm{NH}_{4}^{+}$in soil. Another significant predictor of arginine ammonification is water, or, more precisely, water content. Intensity of arginine ammonification under significant influence of water content, both within the whole monitored season and within the individual months (Table 1), with the exception of May when this relationship showed statistically nonsignificant negative correlation. Very strong correlation of water content and arginine ammonification is evident also from the aspect of SilvPra, being the least distinctive in STFA (thinning from above) and the strongest in MSS (mature stand). Intensity of arginine ammonification in relation to the content of $\mathrm{N}-\mathrm{NH}_{4}{ }^{+}$is characterized by a reverse trend, accompanied by a higher number of negative correlation coefficients in the individual months and overall inversely proportional trend in SilvPra, where the only statistically significant correlation coefficient was found in STFA.

Relationships between arginine ammonification and predicting factors (soil moisture, ammonium nitrogen content, MONTH, SilvPra) are described through a generalized linear model (Table 2). The two considered models, of which the first one (m1) covers the influence of water content and content of $\mathrm{N}-\mathrm{NH}_{4}{ }^{+}$and the second one (m2) only water content as continuous variables, show

Table 1. Mean values and standard deviation of water content $(\mathrm{w})$, ammonium nitrogen content $\left(\mathrm{N}-\mathrm{NH}_{4}^{+}\right)$and arginine ammonification (Arg.: $\mathrm{N}-\mathrm{NH}_{4}^{+}$) and Spearman's correlation coefficient $\left(\mathrm{r}_{\mathrm{s}}\right.$ ) for each group of variables (MONTH and SilvPra). Statistically significant values $p$ are highlighted in Italic font. MSS - mature spruce stand, STFA - stand thinned from above, STFB - stand thinned from below.

\begin{tabular}{|c|c|c|c|c|c|c|c|c|c|}
\hline \multirow[t]{2}{*}{ Month } & \multicolumn{2}{|c|}{$\begin{array}{c}\mathrm{w} \\
{[\%]}\end{array}$} & \multicolumn{2}{|c|}{$\begin{array}{l}\mathrm{N}-\mathrm{NH}_{4}^{+} \\
{\left[\mu \mathrm{g} \mathrm{g}^{-1}\right]}\end{array}$} & \multicolumn{2}{|c|}{$\begin{array}{l}\text { Arg.: } \mathrm{N}-\mathrm{NH}_{4}^{+} \\
{\left[\mathrm{\mu g} \mathrm{g}^{-1} \mathrm{hr}^{-1}\right]}\end{array}$} & \multicolumn{2}{|c|}{$\mathrm{r}_{\mathrm{s}}$} & \multirow[t]{2}{*}{$\mathrm{n}$} \\
\hline & mean & $\mathrm{sd}$ & mean & $\mathrm{sd}$ & mean & sd & Arg. * w & Arg. ${ }^{*} \mathrm{~N}-\mathrm{NH}_{4}^{+}$ & \\
\hline May & 53.38 & 7.63 & 45.99 & 24.40 & 7.11 & 1.12 & -0.017 & 0.471 & 9 \\
\hline June & 35.07 & 4.54 & 13.05 & 6.77 & 4.66 & 0.91 & 0.800 & -0.233 & 9 \\
\hline July & 45.86 & 9.90 & 25.10 & 6.68 & 3.58 & 0.85 & 0.600 & 0.750 & 9 \\
\hline August & 48.31 & 6.77 & 39.86 & 35.65 & 3.31 & 0.57 & 0.450 & -0.783 & 9 \\
\hline September & 64.03 & 2.46 & 11.96 & 8.48 & 12.65 & 4.09 & 0.150 & -0.417 & 9 \\
\hline Seasonal & 49.33 & 11.55 & 27.19 & 23.73 & 6.26 & 3.99 & 0.656 & -0.207 & 45 \\
\hline \multicolumn{10}{|l|}{ SilvPra } \\
\hline STFA & 52.49 & 10.30 & 15.92 & 10.45 & 6.31 & 2.96 & 0.395 & -0.459 & 15 \\
\hline STFB & 46.93 & 14.06 & 19.39 & 11.70 & 7.26 & 5.79 & 0.719 & -0.171 & 15 \\
\hline MSS & 48.57 & 9.91 & 46.27 & 30.54 & 5.21 & 2.31 & 0.674 & -0.300 & 15 \\
\hline
\end{tabular}

Table 2. The resulting model describing the relationship between the study variables (arginine ammonification depending on water content and $\mathrm{N}-\mathrm{NH}_{4}^{+}$) in the months of May to September (MONTH) and various types of management (SilvPra); two final models, including two continuous variables w: soil water and $\mathrm{N}-\mathrm{NH}_{4}^{+}(\mathrm{m} 1)$ and one continuous variable w: soil water $(\mathrm{m} 2)$ are given below. The test criteria are described using vif (variance inflance factor), AIC (Akaike's an information Criterion) and $\mathrm{R}^{2}$ (coefficient of determination). Statistically significant $\mathrm{p}$-value are highlighted in Italic font. MSS - mature spruce stand, STFA - stand thinned from above, STFB - stand thinned from below.

\begin{tabular}{|c|c|c|c|c|c|c|c|c|c|}
\hline Coefficients & p-value ${ }^{m 1}$ & p-value m2 $^{2}$ & variable & $\operatorname{vif}^{\mathrm{m} 1}$ & vif $^{\mathrm{m} 2}$ & $\mathrm{AIC}^{\mathrm{m} 1}$ & $\overline{\mathrm{AIC}^{\mathrm{m} 2}}$ & $\overline{\mathrm{R}^{2 \mathrm{~m} 1}}$ & $\overline{\mathrm{R}^{2 \mathrm{~m} 1}}$ \\
\hline Intercept (including May and MSS) & $3.48 \mathrm{E}-06$ & $1.26 \mathrm{e}-06$ & - & - & - & 135.682 & 135.045 & 0,915 & 0,912 \\
\hline w: soil water [\%] & 0.021365 & 0.023663 & w:soil water [\%] & 5.506 & 5.467 & & & & \\
\hline $\mathrm{N}-\mathrm{NH}_{4}^{+}$ & 0.287766 & - & $\mathrm{N}-\mathrm{NH}_{4}^{+}$ & 5.842 & - & & & & \\
\hline MONTH H - Jun & 0.500667 & 0.136274 & MONTH & 18.993 & 5.475 & & & & \\
\hline MONTH - Jul & $4.44 \mathrm{E}-06$ & $2.78 \mathrm{e}-07$ & & & & & & & \\
\hline MONTH-Aug & $2.38 \mathrm{E}-08$ & $9.82 \mathrm{e}-09$ & & & & & & & \\
\hline MONTH - Sept & 0.007777 & 0.004177 & & & & & & & \\
\hline SilvPra - STFA & 0.028702 & 0.029675 & SilvPra & 2.693 & 1.040 & & & & \\
\hline SilvPra-STFB & 0.000732 & 0.000118 & & & & & & & \\
\hline
\end{tabular}

$\mathrm{m} 1: \mathrm{y} \sim \mathrm{w}+\mathrm{N}-\mathrm{NH}_{4}^{+}+\mathrm{MONTH}+$ SilvPra

$\mathrm{m} 2: \mathrm{y} \sim \mathrm{W}+\mathrm{MONTH}+$ SilvPra

Equation $^{\mathrm{m} 2}$ (arginine ammonification)

$\mathrm{y}=1 /\left[0.27325-0.00201 \times_{\mathrm{w}}+0.03467\right.$ (Jun) $+0.12294(\mathrm{Jul})+0.14967$ (Aug) -0.03887 (Sept) -0.02366 (STFA) -0.04205 (STFB) 
the effects of MONTS and SilvPra on arginine ammonification. In $\mathrm{m} 1$, the effect of $\mathrm{N}-\mathrm{NH}_{4}^{+}$concentration was classified as insignificant $(p=0.287766)$ - despite to high coefficient of determination $\mathrm{R}^{2}$. After elimination of ammonium content from the model ( $\mathrm{m} 2$ ), the $\mathrm{p}$-value for w (water content) slightly increased, while the importance of the individual months as predictors of arginine ammonification decreased. Variance inflation factor (vif) indicated multicollinearity of regressors MONTH in the case of $\mathrm{m} 1$, which was removed together with the factor $\mathrm{N}-\mathrm{NH}_{4}^{+}($vif $<10$ and close to 5$)$. In the $\mathrm{m} 2$ model, the markedly lowest value is the AIC indicating an insignificant difference in the explanatory power of the models.

After close inspection of the relationships (Fig. 5, Fig. 6) between the individual parameters by regression

a)

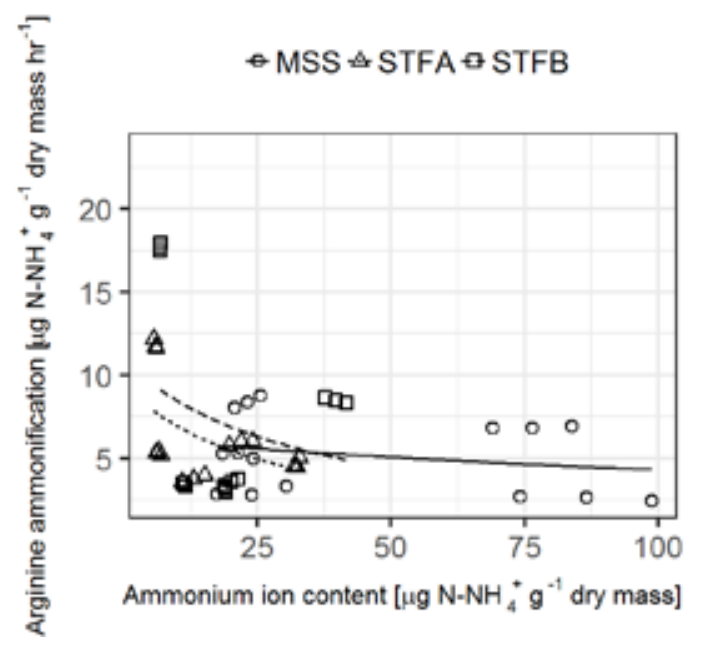

analysis, the content of ammonium nitrogen also shows negative correlation, nevertheless, for the final model it seems to be an insignificant predictor. According to Table 1, the link between arginine ammonification and content of ammonium nitrogen was the closest in August while in the other months it was more or less indifferent. In August, the dependency is markedly negative at a very low content of $\mathrm{N}-\mathrm{NH}_{4}^{+}$and with its increasing concentration, the link between the intensity of arginine ammonification and concentration of ammonium nitrogen assumes an opposite trend: although the overall intensity of arginine ammonification increases, it becomes negatively dependent on $\mathrm{N}-\mathrm{NH}_{4}^{+}$concentration while in the same period, the role of water content increases. From the aspect of SilvPra, there is closer dependency (negative again) of

b)

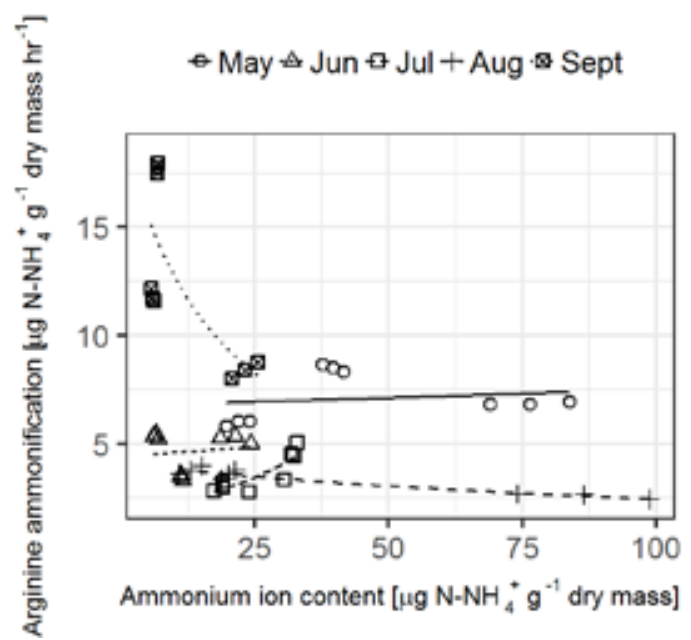

Fig. 5. Arginine ammonification $\left[\mu \mathrm{g} \mathrm{N}-\mathrm{NH}_{4}^{+} \mathrm{g}^{-1}\right.$ dry mass $\left.\mathrm{hr}^{-1}\right]$ in relation with ammonium content $\left[\mu \mathrm{g} \mathrm{N}-\mathrm{NH}_{4}^{+} \mathrm{g}^{-1}\right.$ dry mass] and MONTH (a) and SilvPra (b). MSS - mature spruce stand, STFA - stand thinned from above, STFB - stand thinned from below.

a)

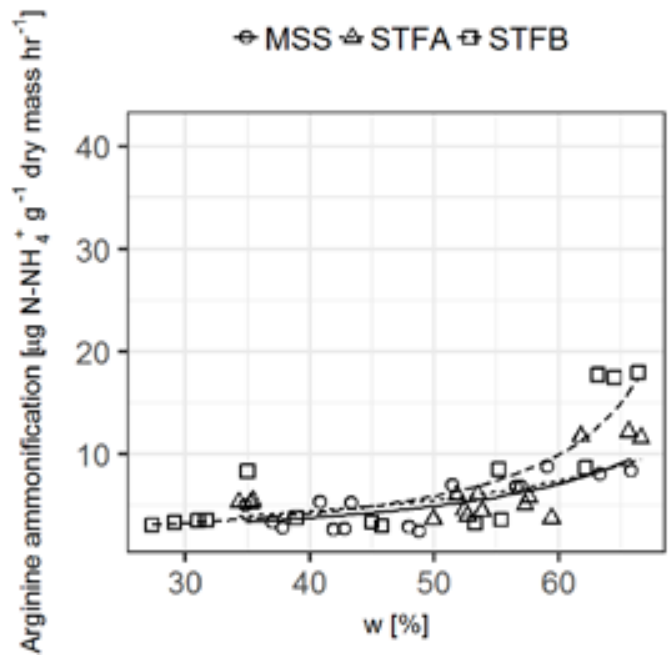

b)

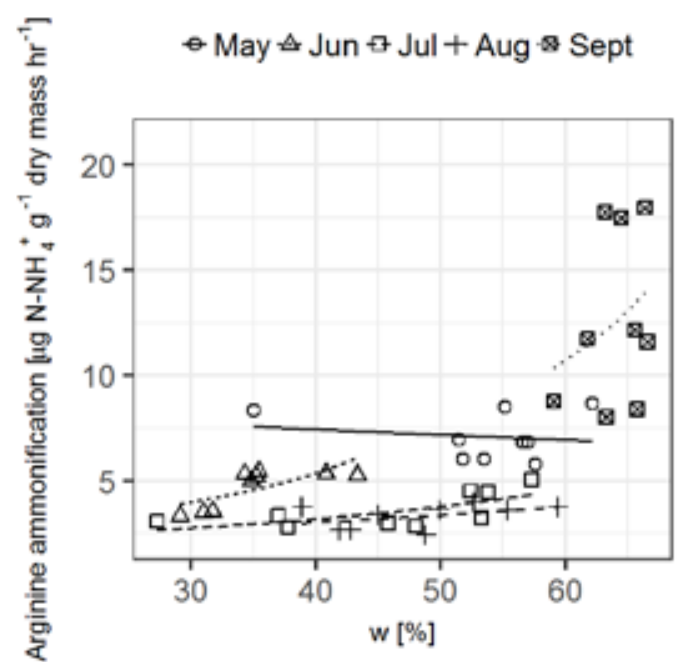

Fig. 6. Arginine ammonification $\left[\mu \mathrm{g} \mathrm{N}-\mathrm{NH}_{4}^{+} \mathrm{g}^{-1}\right.$ dry mass $\mathrm{hr}^{-1}$ ] in relation with soil water content [\%] and MONTH (a) and SilvPra (b). MSS - mature spruce stand, STFA - stand thinned from above, STFB - stand thinned from below. 
arginine ammonification on the content of ammonium $\mathrm{N}$ in the thinned (younger) stands. Firstly, they are predetermined by their generally low maximum content of $\mathrm{N}-\mathrm{NH}_{4}^{+}$in soil (max. $42 \mu \mathrm{g} \mathrm{g}^{-1}$ dry mass) compared to MSS, secondly, the negative correlations prevailing here (stronger in the younger thinned stands) correspond to the fact that the maximum ammonification of arginine in MSS does not exceed $8.8 \mu \mathrm{g} \mathrm{N}-\mathrm{NH}_{4}^{+} \mathrm{g}^{-1} \mathrm{hr}^{-1}$, while in STFA and STFB it reaches more than 12 or even $18 \mu \mathrm{g} \mathrm{N}-\mathrm{NH}_{4}^{+} \mathrm{g}^{-1} \mathrm{hr}^{-1}$, respectively, precisely at the end of the vegetation season in September. From the above said it can be concluded that the tendency to ammonify arginine decreases with stand age as well as with increasing overall content of ammonium nitrogen.

The relation between water content and arginine ammonification is markedly positive as with increasing water content, intensity of ammonification increases, with the trend culminating in September (Fig. 6b). A slight decrease of ammonification (negative relation to water content) was observed in May; at the beginning of the vegetation season, still indifferent reaction of soil biota to changes in water content is to be expected, while at the end of summer, it culminates. Of the stand types (Fig. 6a), the closest relation appeared in STFB; in case of STFA and MSS, the trend is less significant and markedly steady.

\section{Discussion}

Stand thinning leads to higher penetration of light through the canopy, which provokes higher activity and increased population density of soil biota (Tang et al. 2005; Vranová et al. 2010). Thus the overall potential of soil for arginine ammonification increases as well. In this context, it is possible to identify two, or eventually three factors considerably determining the ammonification of arginine in forest soils under spruce stands: (1) content of $\mathrm{N}-\mathrm{NH}_{4}^{+}$, when with its increased content, the "motivation" of soil biota to obtain ammonium nitrogen from an amino-acid by such energy-intensive way decreases - from the aspect of statistical significance it cannot be seen as implicitly significant; (2) type of forest management, or more precisely, its consequences in the form of stand and soil microclimate alteration thinning operations that ensure better opening-up of the canopy and subsequent reaction of soil biota in the form of increased activity and population growth (Vesterdal et al. 1995; Gömöryová et al. 2014); and (3) water content (Bonde at al.2011). Hence, the arginine ammonification culminates at optimum conditions, i.e. at increased water content, generally lower content of ammonium nitrogen and in soil environment with higher population density following a thinning operation.
There is a knowledge gap in the present literature about the direct impact of arginine ammonification on forest soil and availability of nitrogen. Arginine is an important proteinogenic amino acid; and its hydrolysis may play a significant role in nitrogen cycling in forest soils (Moe 2013). From the obtained results it is evident that the controlled laboratory experiments confirmed its seasonal dynamics, as well as its close link to forest management, but also to contextual soil properties, such as soil water content and ammonium nitrogen content.

Measurements carried out in the framework of this study confirm the findings of studies by other authors. For example, Edwards et al. (2006) or Weintraub \& Schimel (2005) describe an increase in microbial activity and thus microbial nitrogen in the fall, in early spring its rapid decline and then its increase again during the late spring (May). Pandey \& Singh (2006) also indicate a close correlation between arginine deaminase activity and respiratory activity of the soil and the amount of carbon in the soil.

\section{Conclusions}

The presented study generally confirmed the ammonification of arginine as significantly depending on seasonal dynamics, forest management and soil properties such as soil water content and ammonium nitrogen content. As the arginine is considered as a significant source of nitrogen after the decomposition of proteins, our findings can be regarded as important for nitrogen cycling control, as well as for its availability for soil biota and plants in consequence. In the case of the spruce forest type, arginine seems to copy the trend of intensifying decomposition with the late spring increase of temperatures (after the winter) and with the increasing amount of dead organic matter at the end of the vegetation season. Beside to the seasonal weather variation, the arginine ammonification significantly depends on stand microclimate being influenced by forest management (technique of thinning), which surprisingly can partially even hide the effect of the season (month). The results of observed seasonal dynamics of arginine ammonification in soil $\mathrm{H}$-horizon in spruce monocultures of different ages and silvicultural practices in medium altitudes support the longstanding perception of ammonification of proteinogenic amino acids as an important part of dead organic matter decomposition.

\section{Acknowledgement}

This research was supported by Internal Grant Agency of FFWT, MENDELU, Czech Republic No. 55/2013-2015, and with project NAZV No. QJ1320040 (Revitalization of ecosystem units with the use of ecological principles on the sites with strong anthropic influence in the past and extreme sites). 


\section{References}

Abdelal,A. T., 1979: Arginine catabolism by microorganisms. Annual Review of Microbiology, 33:139-168.

Alef, K., Kleiner, D., 1986: Arginine ammonification, a simple method to estimate microbial activity potentials in soil. Soil Biology and Biochemistry, 18:233235.

Bonde, T. A., Nielsen, T. H., Miller, M., Sørensen, J., 2001: Arginine ammonification assay as a rapid index of gross $\mathrm{N}$ mineralization in agricultural soils. Biology and Fertility of Soils, 34:179-184.

Davis, R. H., Weiss, R. Ld., Bowman, B. J., 1978: Intracelular metabolite distribution as a factor in regulation in Neurostpora. In: Srere, P. A., Estabrook, R. W. (eds.): Microenvironment and Cellular Compartmentation, Academic Press, New York, p. 197-210.

Edwards, K. A., McCulloch, J., Kershaw, G. P., Jefferies, R. L., 2006: Soil microbial and nutrient dynamics in a wet arctic sedge meadow in late winter and early spring. Soil Biology and Biochemistry, 38:28432851.

Fox, J., Monette, G., 1992: Generalized collinearity diagnostics. Journal of the American Statistical Association, 87:178-183.

Fox, J., Weisberg, S., 2015: Package “car”: Companion to applied regression. Version 2.1-1.

Gömöryová, E., Fleischer, P., Gömöry, D., 2014: Soil microbial community responses to windthrow disturbance in Tatra National Park (Slovakia) during the period 2006 - 2013. Lesnícky časopis - Forestry Journal, 60:137-142.

IUSS Working Group W.R.B., 2006: World Reference Base for Soil Resources 2006. World Soil Resources Report 103, FAO, Rome.

Klinka, K., Krestov, P., Fons, J., Chourmouzis, Ch., 1997: Towards a Taxonomic Classification of Humus Forms: Third Approximation. Scientia Silvica, Extension Series, 9:1-4.

Kučera, A., Holík, L., Marosz, K., Martiník, A., Vavříček, D., 2013: Changes in forms of available nitrogen and respiration in soil of beech forest as a reaction to a deforestation resulting from wind storm. Acta Universitatis Agriculturae and Silviculturae Mendelianae Brunensis, 61:107-113.

Lin, D., 2015: VIF Regression: A fast regression algorithm for large data. Package "vif", version 1.0.

Lin, Q., Brookes, P. C., 1999: Arginine ammonification as a method to estimate soil microbial biomass and microbial community structure. Soil Biology and Biochemistry, 31:1985-1997.
Moe, L. A., 2013: Amino acids in the rhizosphere: from plants to microbes. American Journal of Botany, 100:1692-1705.

Novák, J., Dušek, D., Slodičák, M., 2015: Thinning in artificially regenerated young beech stands. Lesnícky časopis - Forestry Journal, 61:232-239.

Pandey, S., Singh, D. K., 2006: Soil dehydrogenase, phosphomonoesterase and arginine deaminase activities in an insecticide treated groundnut (Arachis hypogaea L.) field. Chemosphere, 63:869-880.

Sakamoto, Y., Ishiguro, M., Kitagawa, G., 1986: Akaike Information Criterion Statistics. Riedel Publishing Company, Netherlands, 290 p.

Singh, J., Singh, D. K., 2005: Available nitrogen and arginine deaminase activity in groundnut (Arachis hypogaea L.) fields after imidacloprid, diazinon, and lindane treatments. Journal of agricultural and food chemistry, 53:363-368.

Tang, J., Qi, Y., Xu, M., Misson, L., Goldstein, A.H., 2005: Forest thinning and soil respiration in a ponderosa pine plantation in the Sierra Nevada. Tree Physiology, 25:57-66.

Vesterdal, L., Dalsgaard, M., Felby, C., Raulund-Rasmussen, K., Jørgensen, B. B., 1995: Effects of thinning and soil properties on accumulation of carbon, nitrogen and phosphorus in the forest floor of Norway spruce stands. Forest Ecology and Management, 77:1-10.

Vranová, V., Holík, L., Rohlík, T., Rejšek, K., Formánek, P., 2010: Carbon, nitrogen, $\mathrm{C} / \mathrm{N}$ ratio and their stand heterogeneity in the soil of Norway spruce stands. Acta Universitatis Agriculturae and Silviculturae Mendelianae Brunensis, 58:413-416.

Wang, H. J., Wu, L. H., Wang, M. Y., Zhu, Y. H., Tao, Q. N., Zhang, F. S., 2007: Effects of amino acids replacing nitrate on growth, nitrate accumulation, and macroelement concentrations in pak-choi (Brassica chinensis L.). Pedosphere, 17:595-600.

Weintraub, M. N., Schimel, J. P., 2005: The seasonal dynamics of amino acids and other nutrients in Alaskan Arctic tundra soils. Biogeochemistry, 73:359-380.

Wickham, H., Chang, W., 2016: An Implementation of the Grammar of Graphics, Package "ggplot2" version 2.1.0.

Yang, L. L., Zhang, F. S., Mao, R. Z., Ju, X. T., Cai, X. B., Lu, Y. H., 2008: Conversion of natural ecosystems to cropland increases the soil net nitrogen mineralization and nitrification in Tibet. Pedosphere, 18:699-706.

Zbíral, J., 2010: Soil Analysis. Vol. 1, Central Institute for Supervising and Testing in Agriculture in Brno, Brno, $199 \mathrm{p}$. 